\title{
MENINGKATKAN KARAKTER CINTA LINGKUNGAN \\ SEBAGAI KEPEDULIAN SISWA TERHADAP PENDIDIKAN \\ LINGKUNGAN HIDUP
}

\author{
Dalintang Ketut Dwi Saputri $^{1)}$, Diana wati ${ }^{2)}$, Anita Trisiana ${ }^{3)}$ \\ ${ }^{1,2)}$ Mahasiswa PPKn Universitas Slamet Riyadi Surakarta \\ ${ }^{3)}$ Dosen PPKn Universitas Slamet Riyadi Surakarta
}

\begin{abstract}
ABSTRAK
Setiap siswa memiliki peran terhadap lingkungan disekitarnya dan juga dapat menciptakan perubahan, terutama dalam kebersihan lingkungan.Keperdulian siswa terhadap lingkungan bisa dilakukan disekolah.Tujuan disini adalah meningkatkan karakter cinta lingkungan sebagai mana keperdulian siswa terhadap pendidikan lingkungan hidup melalui mata pembelajaran. Sehingga disini siswa akan selalu diingatkan dan termotivasi untuk selalu perduli dan cinta terhadap lingkungan. Hal ini dapat dilakukan dengan kebiasaan dan partisipasi. Penerapan pembelajaran inidapat dilakukan dengan caraseperti Pengembanganproses pembelajaran dan pendidikan lingkungan hidup yang mencakup aspek kognitif, afektif, dan psikomotorik.
\end{abstract}

Kata Kunci: Karakter, Lingkungan, Kepedulian

\begin{abstract}
Each student have an important role the environment around them and may also be creating the change, especially in the cleanliness of the environment. Concern Students to the environment could be done at the school. The purpose here is to improve character teach about loving the environment as where concern students to education of the eniveronment by the eye of learning. This can be development of a learning process and education of the living environment includes congnitive aspects, affective, and psychomotor.
\end{abstract}

Keyword: Character Education, Environmental Care, Environmental Education 
PENDAHULUAN

Pendidikan begitu sangat penting untuk dapat merubah karakter perilaku pada siswa untuk bisa menjadikan lebih baik dan terpuji.Pendidikan di lingkungan sekolah ini juga sangat penting karenasebuah tempat dimana pendidikan yang baik untuk mengajarkan dan pembentukan karakter pada siswa adalah sekolahan. Sebab disitulah tempatdimana kegiatan siswa melalui belajar dalam mata pelajaran agar siswa dapat diterapkan pengembangan proses pembelajaran di sekolah dapat meningkatkan karakter pada diri siswa. Pendidikan karakter jugasebuah perihal yang menjadi sekolah yang dapat merubah karakter, dimana sekolah juga suatu tempat terbaik untuk menanamkan sebuah karakter pada diri siswa yang didasarkan pada totalitas psikologi dan juga mencakup potensi untuk setiap individu manusia (kognitif, afektif, dan juga psikomotorik), Thomas Lichona dalam Listyarti (2014: 8). Dari pengertian yang ada bahwa membentuk sebuah karakter pada siswa sangatlah penting.

Dengan adanya suatu kondisi saat ini yang ada di lingkungandapat menimbulkan kekuatiran, dengan timbulnya sebuah permasalah yang tidak lepas dari perilaku manusia itu sendiri, jadi disini siswa sangat perlu sekali untuk dibekali pendidikan karakter tentang cinta dan juga perduli terhadap lingkungan sekitar agar perduli terhadap lingkungan dan juga kebersihan yang ada disekitarnya. Pendidikan dianggap sangatlah penting, pembentukan dan juga merubah karakter pada setiap siswa.Ada juga pendapat menurut Syah,M (2009) juga menyebutkan bahwa perilaku tidak lepas dari pengaruh dari suatu pengalaman dari belajar, melalui pembelajaran ini siswa bisa menyadari akan sesuatu yang dipelajarinya, lalu dapat juga menjadikannya sebuah system nilai pada diri siswa, Oleh sebab itu karakter dapat menjadikan karakter cepat terbentuk jika dilakukannya terus menerus dengan cara seperti itu akan dapat menjadikan sebuah kebiasaan pada diri siswa.

Dengan pengembangan proses pembelajaranyang dilakukan di sekolahjuga dapat dilakukan melalui Guru dengan merencanakan proses pembelajaran dengan baik untuk membangun perilaku karakter dalam kegiatandalam suatu pembelajaran yang dapat dilakukan melalui mata pelajaran tentang karakterakan keperdulian terhadap lingkungan, dapat selalu 
mengingatkan dan juga memotivasi siswa agarbisa terbentuksebuah karakter yang ingin dicapai seperti keperdulian siswa terhadap lingkungan disekitarnya. Contohnya saja siswa akan perduli terhadap sebuah kebersihan dan tentu saja akan membuang sampah pada tempatnya dan tidak akan membuang di sembarangan tempat atau membuang di sekitar lingkungan sekolah. Pendidikan juga diatur dalam sebuahUndangUndang Republik Indonesia Nomor 20 Tahun 2003 yang membahas terkait Sistem Pendidikan Nasional membahas tentang bahwa suatu pendidikan merupakan usaha agar sadar dan juga terencana agar terwujudnya suatu proses pembelajaran agar siswa aktif dan juga dapat mengembangkan potensi pada dirinya. Karakter perduli lingkungan ini juga bukan saja sepenuhnya talenta akantetapi dari bawaan, tetapi juga merupakan suatu hasil dari suatu proses pendidikan. penanaman,

pemahaman,dan juga kesadaran tentang begitu pentingnya menjaga suatu kualitas lingkungan karena sangat pentingnya dan juga baik apabila diterapkan melalui sebuah proses pendidikan.

\section{METODE}

Penelitian saat ini menggunakan pendekatan kualitatif dan juga desain penelitian dengan membahas dan memakai studi kasus. Dikarenakan penelitian ini sangat difokuskan pada peristiwa yang dipilih danjuga dipahami secara mendalam, agar dapat meningkatkankarakter cinta dan juga perduli akan lingkungan, merupakansebuah keperdulian siswa terhadap pendidikan lingkungan hidup. Teknik analisis data penelitian ini menggunakan sebuah metode analisis data interaktif miles dan juga huberman yang meliputi tiga tahap yaitu kondifikasi data, penyediaan suatu data, dan juga mengambil sebuah kesimpulan (Afrizal, 2015:178).Oleh karena itu mengenai materi ajar ini juga bisamengembangan sebuah proses pembelajaran dalam pendidikan lingkungan hidup.

\section{PEMBAHASAN}

\section{Definisi Pendidikan Karakter}

Pendidikan jugamempunyai sebuahperan penting dalam sebuah tahapan hidup manusia dalam melalui suatu proses pendidikan, manusia harus memiliki bekal untuk membentuk sebuah karakter positif dan juga dapat mengembangkan potensi yang dimiliki, Noeng Muhadjir (Wiji Suwarno, 2009:19). Jadi dapat disimpulkan bahwa pendidikan sangat dibutuhkan dalam kehidupan sebab sangat penting sekali untuk membekali siswa agar memiliki karakter yang baik dan juga dapat 
mengembangkan potensi pada diri siswa, oleh karena itu perlu setiap siswa akan mengalami pertumbuhan dan juga perkembangan jadi perlu sekali diimbangi dengan pendidikan, agar siswa tidak berbuat semena-mena dan tidak menyalahgunakan potensi yang telah ada pada diri siswa.

Karakter merupakansebuah kebiasaan-kebiasaan perilaku yang sudah melekat pada diri manusia. Abdullah Munir (2010: 3) buku ini menegaskan bahwa karakter itu merupakan sebuah pola, baik itu pikiran, sikap, maupun tindakan, yang melekat pada diri seseorang dengan sangat kuat dan sulit dihilangkan. Jadi dari beberapa pendapat pengertian yang ada dapat disimpulkan bahwa karakter itu suatu perilaku yang sudah melekat pada diri manusia dan juga sebuah pola dimana agar pikiran, sikap dan juga tindakan tetap selalu melekat danbahkan akan sulit hilang.Karena kebiasaankebiasaan yang selalu dilakukan terus menerus yang dapat membentuk karakter yang positif caranya dapat melalui pendidikan karakter pada siswa.

Pendidikan karakter juga merupakan upaya sungguh-sungguh untuk membantu seseorang untuk memahami, perduli dan juga agar bertindak sesuai dengan nilai-nilai karakter yang ada.Jadi pendidikan karekter itu merupakn usaha dimana bertujuan untuk membentuk karakter atau kepribadian yang dapat dilihat dari suatu perilaku positif dan juga dilakukan secara konsisten sehingga dapat menjadi kebiasaan-kebiasaan yang akan melekat pada diri siswa, tidak itu saja akan tetapi pendidikan karakter ini juga dapat membentuk sebuah moral dan juga kepribadian, maupun akhlak pada diri siswa. Jadi sangat diperlukan sekali dengan adanya nilai-nilai karakter ini dapat membantu siswa untukpengembangan proses pembelajaran melalui pendidikan karakter peduli lingkungan yangdapat dilakukan disekolah.

Selanjutnya Trisiana, A. dan Sutoyo. (2017) :Strategies of Teaching Materials Development of Character Based Civic Education.

\section{Pendidikan}

Peduli

\section{Lingkungan}

Pendidikan dapat membantu siswa dalam meningkatkan keperduliannya akan lingkungan, seperti yang dijelaskan dalam UndangUndang 32 Tahun 2009 membahas Perlindugan \& Penggelolaan Lingkungan Hidup pasal 1 ayat 2, perlindungan dan pengelolaan hidup adalah upaya sistematis dan juga terpadu. Pendidikan karakter perduli lingkungan ini merupakan 
pengembangan dari nilai-nilai karakter, seperti mencakup : Religious, Jujur, Toleransi, Disiplin, Kerja Keras, Kratif, Mandiri, Demokratis, Rasa Ingin Tahu, Semangat Kebangsaan, Cinta Tanah Air, Menghargai Prestasi, Bersahabat dan Komunikatif, Cinta Damai, Gemar Membaca, Peduli Lingkungan, Peduli Sosial, dan Tanggung Jawab.

Pendidikan peduli lingkungan ini dapat dikembangkan di sekolah sebab karena termasuk dari karakter. Peduli lingkungan ini merpakan suatu sikap dan tindakan yang berupaya mencegah kerusakan pada lingkungan di sekitar dan berupaya untukbisa memperbaiki kerusakan alam.Ini alasan dimana sangatlah penting pendidikan karakter khususnya pada peduli lingkungan hidup diterapkan pada siswa, karena setiap siswa harus cinta lingkungan untuk selalu terbiasa untuk memelihara kebersihan dan kelestaraian lingkungan disekitar.

3. Pengembangan Dalam Suatu Proses Pembelajaran

\section{Kementrian Pendidikan}

Nasional (2010:20) Pembelajaran menggunakan pendekatan proses belajar peserta didik secara aktif dan juga berpusat pada anak dalam pembelajaran pendidikan peduli lingkungan ini dapat dilakukan juga dengan melalui:
1) Kelas, dengan melalui ini proses pembelajaran dan kegiatan yang dirancang untuk meningkatkan kemampuan kognitif, afektif, psikomotorik. Pengembangan nilai karakter peduli lingkungan ini juga dilakukan didalam kelas agar siswa dapat memiliki kesempatan untuk mengembangkan nilai-nilai seperti disiplin, jujur, dan kerja keras.

2) Sekolah, suatu dapat menjadi tempat untuk mengembangkan karakter peduli terhadap lingkungan, semisal sekolah meningkatkan, menanamkan pelaksanaan karakter peduli lingkungan dengan cara perlombaan kebersihan kelas, sebagai budaya sekolah. Bisa juga dilakukan rutin bahkan bisa juga dimasukan dalam kalender akademik.

3) Luar Sekolah, seperti kegiatan ekstrakulikuler, contoh saja pramuka dimana kegiatan ekstrakulikuler ini yang berupa kegiatan yang berhubungan dengan alam yang dapat meningkatkan karakter peduli terhadap lingkungan. 
4. Pendidikan karakter Peduli Lingkungan melalui Pembelajaran Pendidikan Lingkungan Hidup

pembelajaran

pendidikan

lingkungan hidup ini dapat lebih dahulu membuat Rencana Pelaksanaan Pembelajaran (RPP) tujuannya untuk gambaran sebelum dajarkan dan juga diterapkan dalam pembelajaran.

1) Kognitif

Mempu memahami dan jugadapat mengetahui permasalahan lingkungan yang ada disekitar . Jadi siswa dapat mengetahui dan juga mampu memahami permasalahan terhadap lingkungan terutama di dalam lingkungan sekolah dan juga di sekitarnya.Kalau pembelajaran dapat juga menggunakan obyek tumbuhan. Agar siswa dapat mengetahui lebih gampang memahami tentang permasalahan yang ada di lingkungan sekolah seperti mengenai membuang sampah sembarangan akan mengakibatkan lingkungan kotor, bahkan bisa sampai banjir.

2) Afektif

Sebuah Kesadaran dan juga sikap, dan juga perilaku, dapat meningkatkan partisipasi siswa didalam peduli lingkungan hidup.Aspek afektif ini dapat dilihat dari perilakupada diri siswa, dan dengan kesebalikannya dengan kognitif, dimana afektif sikap kesadaran contohnya agar siswa dapat menjaga lingkungan dengan membuang bekas bungkus jajan ke tempat sampah. Dengan partisipasi siswa memecahkan permasalahan yang ada dilingkungan di sekitar, dan bukan itu saja siswa juga bisa meningkatkan karakter cinta dan peduli terhadap lingkungan dengan diajarkan merawat tumbuhan dan juga tanaman kemudian memberi pupuk.

3) Psikomotorik

Siswa dapat memiliki ketrsmpilan yang efektif dan aplikatif.

Dalam pendidikan lingkungan hidup siswa bisa memiliki ketrampilan ini dapat juga membuat ketrampilan dari bahan yang sudah tidak digunakan seperti barang bekas, dapat juga menjadikan siswa menjadi seorang entrepreneur. 


\section{KESIMPULAN}

Berdasarkan hasil pembahasan, maka dapat disimpulkan bahwa pendidikan karakter peduli lingkungan hidup dapatmelalui:

a. Pengembangan proses pembelajaran, yang meliputi proses pembelajaran yang dilakukan di kelas, sekolah dan juga di luar sekolah. Di Kelas dengan praktek atau pengamatan langsung. dapat dilakukan kegiatan yang melibatkan siswa dan juga lingkungan, penggembangan dengan cara menjelaskan pembelajaran yang sesuai dengan tujuan yang akan dicapai.

b. dikembangkan dengan melalui Rencana Pelaksanaan

Pembelajaran (RPP) sebab untuk acuan atau gambaran dimana sebelum diterapkan pada siswa. Pembelajaran ini juga dapat diterapkan dikelas, bahkan juga di lingkungan. Pembelajaran juga mencakup tiga aspek untuk dapat meningkatkan karakter peduli lingkungan yaitu mencakup aspek kognitif, afektif, dan juga psikomotorik. Dan perlu diadakan juga evaluasi agar dapat mengetahui ketercapaian tujuan.

SARAN

Berdasarkan kesimpulan diatas dapat diajukan saran sebagai berikut:

1. Bagi Kepala Sekolah Membuat suatu program perlombaan kebersihan kelas dan juga diberikan hadiah agar siswa bersemangat. Dan juga sekolah dipasang seperti poster-poster, menyediakan Tempat sampah organic dan juga non organic siswa juga diajarkan agar dapat kreatif untuk memanfaatkan barang bekas jadi barang berguna dan mempunyai nilai jual. Dan sekolah juga lebih tegas dalam memberi sanksi terkait dengan proses pelaksanaan terhadap kegiatan peduli lingkungan sesuai dengan tata tertib yang sudah ada disekolah.

2. Bagi Guru menyiapkan RPP dengan baik sebelum mengajar agar mempunyai 


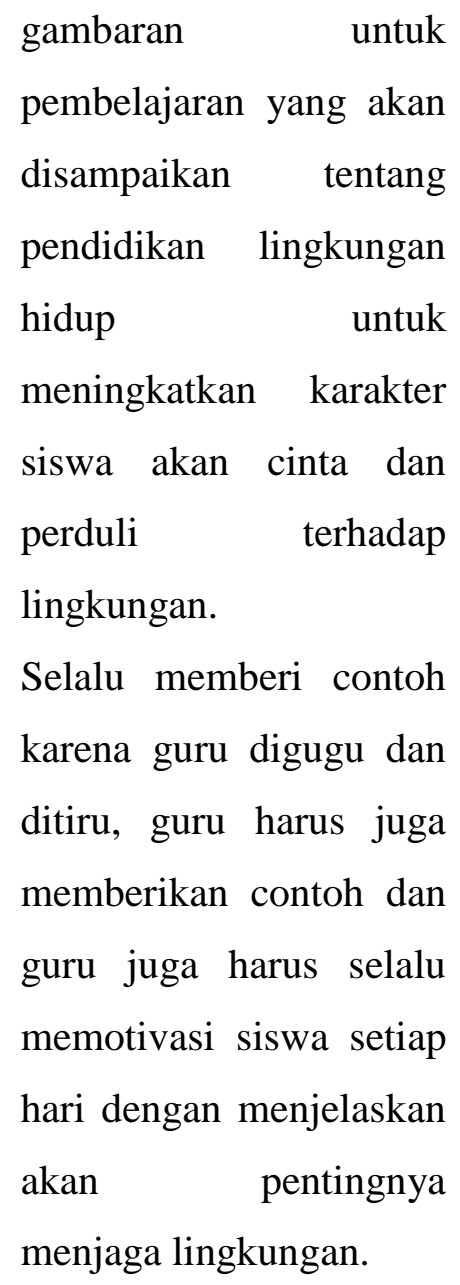

3. Bagi siswa

Harus selalu menaati peraturan yang ada, dan juga mempunyai sebuah kesadaran akan kebersihan lingkungan. Dan juga siswa dapat meningkatkan karakter peduli lingkungan yang telah diajarkan di dalam mata pembelajaran dan sehingga menjadi pribadi-pribadi siswa yang perduli akan lingkungan hidup. 


\section{DAFTAR PUSTAKA}

Abdullah Munir. (2010). Pendidikan Karakter: Membanggun Karakter Anak Sejak dari Rumah. Yogyakarta: Pedagogia

Afrizal.2015. Metode Penelitian Kualitatif: Sebuah Upaya Mendukung Penggunaan Penelitian Kualitatif dalam Berbagai Disiplin Ilmu. Jakarta: PT Raja Grafindo Persada.

Kementrian Pendidikan Nasional.(2010). Pengembangan Pendidikan Budaya dan Karakter Bangsa. Jakarta

Listyarti, Retno. 2014. Pendidikan Karakter dalam Metode Aktif, Inovatif, dan Kreatif. Jakarta:Esensi.
Syah, M. 2009. Psikologi Belajar. Jakarta: PT Grafindo Persada

Trisiana, A., \& Sutoyo (2017).Strategies Of Materials Development Of Character Based Civic Education

Undang-Undang Republik Indonesia Nomor 20 Tahun 2003 tentang Sistem PendidikanNasional.

Undang-Undang Republik Indonesia Nomor 32 tahun 2009 Tentang Perlindungan dan Pengelolaan Lingkungan Hidup

Wiji Suwarno. (2009). Dasar-Dasar Ilmu Pendidikan. Yogyakarta: Ar - Ruzz Media. 